\title{
NON-TRADITIONAL WHITEWARE BASED ON CALCIUM ALUMINATE CEMENT
}

\author{
NETRADICIONALNI PORCELAN NA OSNOVI KALCIJ \\ ALUMINATNEGA CEMENTA
}

\author{
Radomir Sokolar \\ Brno University of Technology, Faculty of Civil Engineering, Veveri 95, 60200 Brno, Czech Republic \\ sokolar.r@fce.vutbr.cz \\ Prejem rokopisa - received: 2015-07-01; sprejem za objavo - accepted for publication: 2015-10-27
}

doi: $10.17222 /$ mit.2015.182

\begin{abstract}
The article introduces the differences in the properties of whiteware (porosity, strength, thermal expansion coefficient) when a non-traditional binder is used. Pure calcium aluminate cement and a mixture of kaolin and calcium aluminate cement compared with traditional plastic raw material for whiteware - kaolin - are used for the preparation of whiteware bodies with a constant content of non-plastic raw materials: K-Na feldspar and quartz sand. The results are discussed in connection with the microstructure of the fired body of prepared whitewares (mineralogical composition). Calcium aluminate cement (CAC) in whiteware raw-material mixtures is an interesting alternative to kaolin for a higher strength of the green and fired bodies. Using calcium aluminate cement reduces the sintering temperature of the fired body and significantly changes its mineralogical composition: anorthite is the main mineralogical phase instead of mullite, which is typical for standard porcelain bodies made from raw-material mixtures based on kaolin. The coefficient of thermal expansion increases with an increasing content of CAC in the raw-materials mixture.
\end{abstract}

Keywords: calcium aluminate cement, kaolin, whiteware

Članek predstavlja razlike v lastnostih porcelana (poroznost, trdnost, koeficient toplotnega raztezka), če se uporabi neobičajno vezivo. Čisti kalcijev aluminatni cement in mešanica kaolina in kalcijevega aluminatnega cementa, $\mathrm{v}$ primerjavi s tradicionalno plastično sestavino porcelana - kaolina, so bili uporabljeni za keramična telesa s konstantno vsebnostjo neplastičnih surovin; $\mathrm{K}-\mathrm{Na}$ glinenec in kvarčni pesek. Rezultati so razloženi v povezavi z mikrostrukturo telesa pripravljene keramike (mineraloška sestava) po žganju. Kalcijev aluminatni cement (CAC), v mešanici surovin za keramiko, je zanimivo nadomestilo za kaolin, za višjo trdnost zelenega in žganega telesa. Uporaba kalcijevega aluminatnega cementa zniža temperaturo sintranja žganega telesa in močno spremeni njegovo mineraloško sestavo; anortit je glavna mineraloška faza namesto mulita, ki je značilen v standardnih porcelanskih telesih, izdelanih iz mešanice surovin na osnovi kaolina. Koeficient toplotnega raztezka se povečuje $\mathrm{z}$ večanjem vsebnosti CAC v mešanici surovin.

Ključne besede: kalcijev aluminatni cement, kaolin, porcelan

\section{INTRODUCTION}

Whiteware is a traditional ceramic material that has been manufactured for centuries from a mixture of kaolin, quartz and feldspar. A new type of porcelain body the anorthite porcelain body - from feldspar, quartz and calcium aluminate cement without using any other binders and plastic ceramic raw materials (clays, kaolins) - was fabricated at a temperature of $1300{ }^{\circ} \mathrm{C}$ and the physical and mechanical properties were investigated. The addition of calcium aluminate cement as a substitute for clays exhibits a relatively high green strength and lowers the density due to the formation of anorthite in all the fired bodies. ${ }^{1}$

Increasing the strength of the green body, reducing the coefficient of linear thermal expansion and increasing the whiteness of the fired body can be achieved primarily by replacing the kaolin for calcium aluminate cement (70 \% of $\mathrm{Al}_{2} \mathrm{O}_{3}$ ). A negative aspect of using calcium aluminate cement with a high $\mathrm{Al}_{2} \mathrm{O}_{3}$ content is reducing the sintering activity of the body and therefore the need for higher firing temperatures. ${ }^{2}$
The single-phase anorthite ceramic was fabricated (from a mixture of ball clay, quartz, calcite, feldspar and alumina) by slip casting and sintering at $1230{ }^{\circ} \mathrm{C}$ for $1 \mathrm{~h}$. It has a high flexural strength of $103 \mathrm{MPa}$, which is higher than that of the conventional porcelain. The single-phase anorthite ceramic had a relatively low $\left(4.9 \times 10^{-6} \mathrm{~K}^{-1}\right)$ thermal expansion coefficient, which can be easily matched with an applicable glaze and achieve an excellent thermal shock resistance. ${ }^{3}$

A new, porcelainised stoneware material based on anorthite was prepared from an undefined ratio of wollastonite, alumina, quartz, Ukrainian Ball clay and magnesia. After firing at $1220{ }^{\circ} \mathrm{C}$ we obtained a porcelainised stoneware body containing $70 \%$ crystalline and $30 \%$ glassy phases with a high modulus of rupture (110 $\mathrm{MPa}$ ) that is two times higher compared to conventional porcelainised stoneware materials based on mullite. ${ }^{4}$ Calcium aluminate cements are white (according to the $\mathrm{Al}_{2} \mathrm{O}_{3}$ content), high-purity hydraulic bonding agents providing controlled setting times and strength development for today's high-performance refractory products. 
There are only laboratory results in the area of replacing kaolin with CAC for the production of whiteware without any practical industrial impact. The aim of the article is to introduce the differences in the properties (porosity, strength, thermal expansion coefficient) of whiteware when pure calcium aluminate cement or a combination of the binders - a mixture of kaolin and calcium aluminate cement - instead of kaolin is used. The results will be discussed in connection with the mineralogical composition of the fired whiteware body.

\section{CHARACTERIZATION OF USED MATERIALS}

Calcium aluminate cement SECAR ${ }^{\circledR} 51$ (CAC51) with $51 \%$ of $\mathrm{Al}_{2} \mathrm{O}_{3}$ content (on average) was used for the experimental study. Calcium aluminate cement contains mainly $\mathrm{CA}$ and $\mathrm{C}_{12} \mathrm{~A}_{7}, \mathrm{C}_{2} \mathrm{AS}$ and $\mathrm{CT}$ as minor mineralogical phases. The chemical composition is clear from Table 1. SECAR®51 is a fused hydraulic binder with a mineralogy focused on mono-calcium aluminate to give a strong hydraulic activity and impart excellent mechanical properties to conventional concretes. This binder is recommended when rapid hardening properties are required. It is adapted to all types of placing methods, particularly casting and gunning at a service temperature of $1400{ }^{\circ} \mathrm{C}$ and above. The surface area is about $4 \mathrm{~m}^{2} \mathrm{~g}^{-1}$. The equivalent mean spherical diameter (Laser PSD) of CAC51 is $d(0.5)=14 \mu \mathrm{m}$.

Table 1: Typical chemical composition of used binders: calcium aluminate cement CAC51 and kaolin

Tabela 1: Značilna kemijska sestava uporabljenih veziv: kalcijev aluminatni cement CAC51 in kaolin

\begin{tabular}{|c|c|c|c|c|c|c|c|}
\hline Material & $\mathrm{CaO}$ & $\mathrm{Al}_{2} \mathrm{O}_{3}$ & $(\mathrm{~K}) \mathrm{Na}_{2} \mathrm{O}$ & $\mathrm{SiO}_{2}$ & $\mathrm{Fe}_{2} \mathrm{O}_{3}$ & $\mathrm{MgO}$ & LOI \\
\hline CAC51 & 36.9 & 52.2 & $\leq 0.5$ & 4.9 & 1.8 & $\leq 1.0$ & 0.0 \\
\hline Kaolin & 0.7 & 36.6 & 1.2 & 46.8 & 0.9 & 0.5 & 13.2 \\
\hline
\end{tabular}

LOI - lost of ignition

Kaolin Zettlitz Ia is the most renowned and the oldest product of the company Sedlecký kaolin a. s. It has been produced since 1892 when the company Zettlitzer Kaolinwerke AG was founded; the present company Sedlecký kaolin a.s. is its successor. The major features of kaolin Zettlitz Ia are:

- relatively high plasticity, which enables good workability in the raw state,

- easy deflocculation with available deflocculants (addition of $0.1 \% \mathrm{Na}_{2} \mathrm{CO}_{3}$ ),
- high content of $\mathrm{Al}_{2} \mathrm{O}_{3}$ and a low content of alkalis, which provides high stability in fire.

The original use of the kaolin Zettlitz Ia was in porcelain production. Many producers use it today as the main plastic component in bodies for plastic moulding, slip casting or isostatic pressing of tableware. Good plasticity in the raw state and high stability in fire are also employed in the production of ceramic rollers for fast firing kilns. A low content of harmful substances and plasticity play a significant role in pencil production. This feature is also important for use in cosmetics. The mineralogical composition of the used washed kaolin is $91 \%$ of kaolinite, $2 \%$ of quartz and about $7 \%$ of mica minerals. The surface area of the kaolin is $17.5 \mathrm{~m}^{2} \mathrm{~g}^{-1}$.

Industrially milled potassium-sodium feldspar rock and pure quartz sand were used for the experiments as non-plastic materials. The mineralogical composition of the sodium-potassium feldspar is potassium feldspar (microcline) $20.0 \%$, sodium feldspar (albite) $22.6 \%$, calcium feldspar (anorthite) $2.4 \%$ and quartz $55.0 \%$. The chemical composition of the used feldspar rock (Table 2) reflects its mineralogical composition and the volume of different types of pure feldspars (potassium, sodium and calcium).

The micro-milled quartz sand ST 6 from Sklopísek Střeleč Company (Czech Republic) was used. The material is produced by milling in an iron-free environment, by classification with the use of air separators. The raw material used for the production of micro-milled sands, i.e., silica flour, is treated silica sand with a $\mathrm{SiO}_{2}$ content above $99 \%$. The chemical purity, favourable particle size distribution, chemical inertness and the hardness of the micro-milled sands - silica flour - is appreciated in the production of glass fibres, ceramic enamels, glazes, as a filler in plastics, in the production of special mortar mixtures, tile adhesives and in the foundry industry for the production of moulds. The surface area of the used micro-milled quartz sand is $4.38 \mathrm{~m}^{2} \mathrm{~g}^{-1}$.

Granulometries of the milled feldspar and milled quartz were determined according to the particle size distribution (laser particle size analyser Malvern Mastersizer 2000). The equivalent mean spherical diameters $d(0.5)=20.8 \mu \mathrm{m}$ (feldspar) and $16.0 \mu \mathrm{m}$ (quartz sand) are suitable for the production of the porcelain body. ${ }^{5}$

\section{METHODOLOGY}

Three different raw-material mixtures on the basis of different binder bases (calcium aluminate cement

Table 2: Chemical composition of used non-plastic materials: K-Na feldspar rock and quartz sand Tabela 2: Kemijska sestava uporabljenih neplastičnih materialov: K-Na glinenec in kvarčni pesek

\begin{tabular}{|c|c|c|c|c|c|c|c|c|c|c|c|}
\hline & \multicolumn{10}{c|}{ Content, in mass fractions $(w / \%)$} \\
\hline & $\mathrm{SiO}_{2}$ & $\mathrm{Al}_{2} \mathrm{O}_{3}$ & $\mathrm{Fe}_{2} \mathrm{O}_{3}$ & $\mathrm{MnO}$ & $\mathrm{TiO}_{2}$ & $\mathrm{CaO}$ & $\mathrm{MgO}$ & $\mathrm{K}_{2} \mathrm{O}$ & $\mathrm{Na}_{2} \mathrm{O}$ & LOI & Total \\
\hline Feldspar & 79.76 & 12.37 & 0.42 & 0.00 & 0.05 & 0.48 & 0.10 & 3.35 & 2.67 & 0.80 & 100.00 \\
\hline Quartz & 99.60 & 0.20 & 0.03 & - & - & 0.10 & 0.10 & 0.00 & - & - & 100.03 \\
\hline
\end{tabular}

LOI - lost of ignition 
CAC51, washed kaolin and its mixture), industrially milled K-Na feldspar rock and industrially milled glass quartz sand were prepared (Table 3).

Table 3: Composition of raw-material mixtures (test samples) in mass fractions, $(w / \%)$

Tabela 3: Sestava mešanice surovin (preizkusni vzorci), v masnih odstotkih, $(w / \%)$

\begin{tabular}{|c|c|c|c|c|}
\hline Sample & Kaolin & CAC51 & Feldspar & Quartz sand \\
\hline A & 25 & & 50 & 25 \\
\hline B & & 25 & & \\
\hline C & 15 & 10 & & \\
\hline
\end{tabular}

Raw-material mixtures according to Table 3 were homogenized for $24 \mathrm{~h}$ in a homogenizer. The dry mixture was then moistened with $9 \%$ mass of water. The moistened mixtures were pressed through the $1-\mathrm{mm}$ sieve. The pressing granulate was thus prepared and subsequently mixed for $12 \mathrm{~h}$ in the closed plastic vase of the homogenizer to produce a homogenous moisture. Test samples with a green-body size of $100 \mathrm{~mm} \times 50 \mathrm{~mm}$ $\times 10 \mathrm{~mm}$ were uniaxially pressed in a steel mould at 20 MPa with $30 \mathrm{~s}$ of soaking time at the maximum pressure. Drying in air at a temperature of about $21{ }^{\circ} \mathrm{C}$ was followed by final drying in a laboratory drier at $110{ }^{\circ} \mathrm{C}$ to achieve a constant weight.

The green bodies were fired in an electric laboratory furnace at different temperatures with a heating rate $10{ }^{\circ} \mathrm{C} / \mathrm{min}$ and a 30 -min soaking time at the maximum temperature to achieve the sintering temperature, which is defined as the temperature when the fired body has a water absorption $E=2 \%$. The subsequent cooling proceeded spontaneously, following the natural cooling rate of the furnace. After firing, the body properties (6 test samples) were defined according to the official standard EN ISO 10545 (vacuum water absorption Ev, modulus of rupture MOR). The mineralogical compositions of the pure feldspars and fired bodies were determined by X-ray diffraction (XRD). The XRD analysis was performed with a Phillips PW 1170 diffrac- tometer using a $\mathrm{Cu}$ anti-cathode $(\lambda \alpha 1=0.15406 \mathrm{~nm})$, accelerating voltage $40 \mathrm{kV}$, beam current $25 \mathrm{~mA}$ and scanning rate $1^{\circ} 20^{\prime} \mathrm{min}^{-1}$.

\section{RESULTS OF EXPERIMENTS}

The mixtures containing CAC51 (B and C) show a significantly higher sintering activity (the ability of the body to create a compact body during the firing through the merging of the grains) according to dilatometric curves (Figure 1). The sintering activity is described by the shrinkage of the tested samples during the firing. The higher content of CAC51 in the raw-material mixture caused a lower sintering temperature of the body during the firing (Table 4). The sintering temperatures (temperature when the fired body has water absorption $\mathrm{E}=2 \%$ ) are:

Sample A: approximately $1270{ }^{\circ} \mathrm{C}$,

Sample B: approximately $1150{ }^{\circ} \mathrm{C}$

Sample C: approximately $1250{ }^{\circ} \mathrm{C}$

Table 4: Water absorption of fired bodies depending on the firing temperature

Tabela 4: Absorpcija vode v žganih telesih v odvisnosti od temperature žganja

\begin{tabular}{|c|c|c|c|}
\hline \multirow{2}{*}{ Sample } & \multicolumn{3}{|c|}{ Water absorption after the firing (in mass } \\
& \multicolumn{3}{|c|}{ fractions, $(w / \%)$} \\
\cline { 2 - 4 } & $1150{ }^{\circ} \mathrm{C}$ & $1250^{\circ} \mathrm{C}$ & $1270{ }^{\circ} \mathrm{C}$ \\
\hline $\mathrm{A}$ & 10.7 & 4.5 & 1.6 \\
\hline $\mathrm{B}$ & 1.8 & & \\
\hline $\mathrm{C}$ & 7.6 & 1.5 & \\
\hline
\end{tabular}

These are different results than when the calcium aluminate cement with a higher content of $\mathrm{Al}_{2} \mathrm{O}_{3}(70 \%)$ was used. ${ }^{2}$ This situation reflects the different chemical composition of CA cements: CAC51 contains a higher portion of fluxing oxides $\left(\mathrm{Fe}_{2} \mathrm{O}_{3}\right.$ and $\mathrm{CaO}$ especially) to CAC70. The mineralogical composition of all the tested bodies after the firing is characterized by the existence of the quartz and the glass phase. The fired body based on

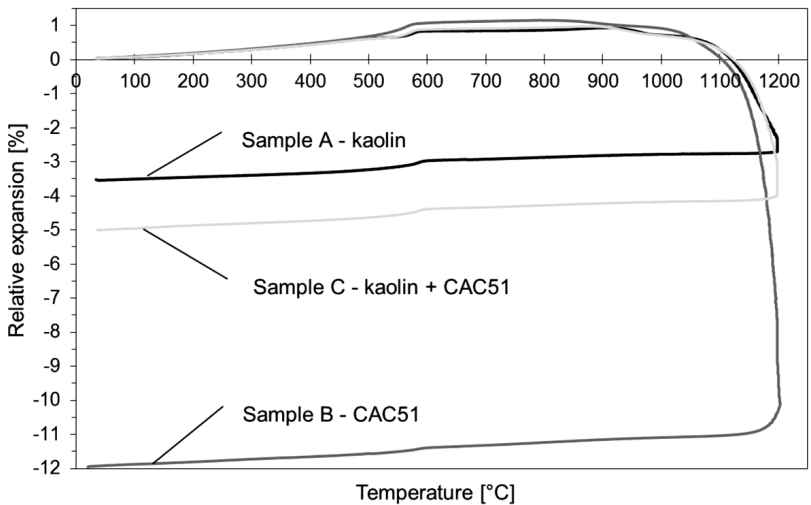

Figure 1: Thermal dilatometric analysis during the firing $\left(1200{ }^{\circ} \mathrm{C}\right.$, $5{ }^{\circ} \mathrm{C} / \mathrm{min}$ without soaking time)

Slika 1: Termična dilatometrična analiza med žganjem $\left(1200{ }^{\circ} \mathrm{C}\right.$, $5{ }^{\circ} \mathrm{C} / \mathrm{min}$ brez časa zalaganja)

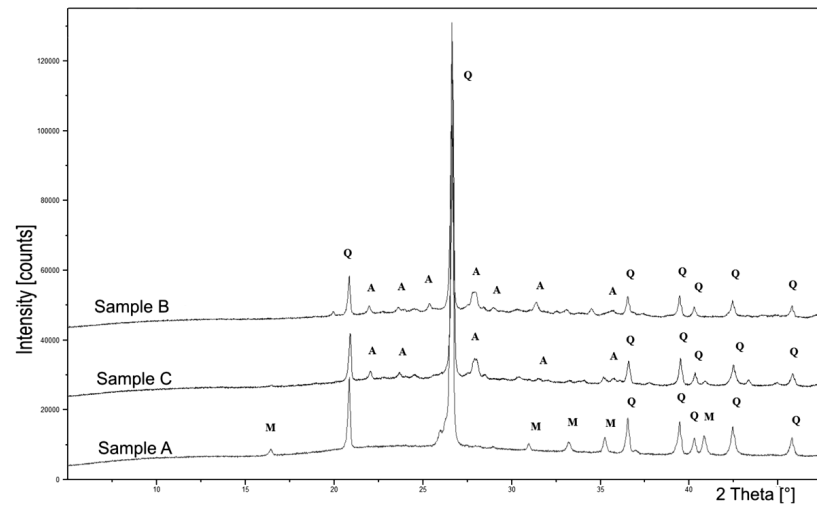

Figure 2: XRD of fired bodies based on different binders: kaolin or CAC51 (M-mullite, Q-quartz, A-anorthite)

Slika 2: Rentgenogram žganih teles na osnovi različnih veziv- kaolin ali CAC51 (M-mulit, Q- kvarc, A-anortit 
kaolin also contains mullite, while the fired bodies based on CAC51 contain anorthite without mullite (Figure 2). In the case of a combination of the binders, the mullite phase is missing.

By comparing the modulus of rupture (MOR) of the fired samples at their sintering temperatures (with similar porosity), it is evident that anorthitic type of body (Figure 2) with a lower content of glass phase (based on calcium aluminate cement) comprises a higher modulus of rupture. This confirms the results published in ${ }^{3,4}$.

Table 5: Modulus of rupture of tested whiteware bodies after the firing at the sintering temperatures

Tabela 5: Prelomni modul preizkušenih porcelanskih teles po žganju na temperaturi sintranja

\begin{tabular}{|c|c|}
\hline Sample & Modulus of rupture $(\mathrm{MPa})$ \\
\hline A & $34.4\left(1270^{\circ} \mathrm{C}\right)$ \\
\hline B & $37.4\left(1150^{\circ} \mathrm{C}\right)$ \\
\hline $\mathrm{C}$ & $33.8\left(1250^{\circ} \mathrm{C}\right)$ \\
\hline
\end{tabular}

The thermal expansion coefficient is the main factor when considering the thermal matching between the glaze and the body, and indirectly influences the thermal shock resistance. ${ }^{6}$ The coefficient of linear thermal expansion was calculated from dilatometric curves (Figure 3 ) in the different temperature ranges from $30{ }^{\circ} \mathrm{C}$ to $1000{ }^{\circ} \mathrm{C}$ (Table 6). The whiteware fired body based on calcium aluminate cement CAC51 (samples B and C) shows a higher coefficient of thermal expansion compared with the kaolin-based sample A (Figure 3). This is an unexpected result due to the formation of anorthite in the samples B and C (Figure 3). A very important technical property of anorthite is its low coefficient of linear thermal expansion coefficient of $4.82 \times 10^{-6} \mathrm{~K}^{-1} 7$ (compared with mullite $\left.6.00 \times 10^{-6} \mathrm{~K}^{-1}\right){ }^{8}$ Different results are achieved when the $\mathrm{CAC}$ with $70 \%$ of $\mathrm{Al}_{2} \mathrm{O}_{3}$ has been used as the replacement for kaolin: the coefficient of linear thermal expansion decreased from $9.24 \times 10^{-6}$ to

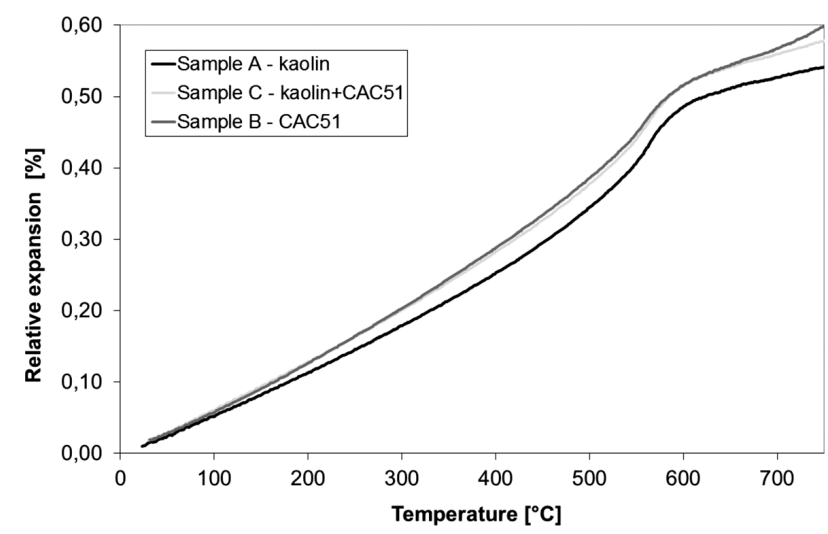

Figure 3: Relative expansion of the fired bodies depending on the temperature for the coefficient of linear thermal expansion determination

Slika 3: Relativni raztezek žganih teles v odvisnosti od temperature pri določanju linearnega toplotnega raztezka
$8.08 \times \cdot 10^{-6} \mathrm{~K}^{-1} .^{2}$ This may be connected with the higher content of $\mathrm{Fe}_{2} \mathrm{O}_{3}$ in CAC51 (Table 1).

Table 6: The values of the coefficient of linear thermal expansion $\alpha$ $\left(\mathrm{K}^{-1}\right)$ depending on the temperature range and raw-materials mixture

Tabela 6: Vrednosti koeficienta linearnega toplotnega raztezka $\alpha$ $\left(\mathrm{K}^{-1}\right) \mathrm{v}$ odvisnosti od temperaturnega območja in mešanice surovin

\begin{tabular}{|c|c|c|c|}
\hline \multirow{2}{*}{$\begin{array}{c}\text { Temperature } \\
\text { range }\end{array}$} & $\mathrm{A}$ & $\mathrm{C}$ & $\mathrm{B}$ \\
\cline { 2 - 4 } & $\alpha \cdot 10^{-6}\left(\mathrm{~K}^{-1}\right)$ & $\alpha \cdot 10^{-6}\left(\mathrm{~K}^{-1}\right)$ & $\alpha \cdot 10^{-6}\left(\mathrm{~K}^{-1}\right)$ \\
\hline $20-200{ }^{\circ} \mathrm{C}$ & 5.73 & 6.43 & 6.35 \\
\hline $20-300^{\circ} \mathrm{C}$ & 6.05 & 6.74 & 6.85 \\
\hline $20-400^{\circ} \mathrm{C}$ & 6.42 & 7.13 & 7.31 \\
\hline $20-500^{\circ} \mathrm{C}$ & 7.01 & 7.63 & 7.83 \\
\hline $20-600^{\circ} \mathrm{C}$ & 8.25 & 8.71 & 8.73 \\
\hline $20-700^{\circ} \mathrm{C}$ & 7.63 & 8.07 & 8.20 \\
\hline $20-800^{\circ} \mathrm{C}$ & 7.15 & 7.71 & 8.20 \\
\hline $20-900^{\circ} \mathrm{C}$ & 6.69 & 7.46 & 7.92 \\
\hline $20-1000^{\circ} \mathrm{C}$ & 6.12 & 7.03 & 7.23 \\
\hline
\end{tabular}

\section{CONCLUSION}

The presence of calcium aluminate cements in the raw-materials mixture significantly changes the mineralogical composition of a fired whiteware body, i.e., anorthite is the main mineralogical phase instead of mullite, which is typical for standard porcelain bodies made from raw-material mixtures based on kaolin. The anorthite type of porcelain body is very suitable for the high strength of the fired body. Using calcium aluminate cement with a lower content of $\mathrm{Al}_{2} \mathrm{O}_{3}(51 \%)$ reduces the sintering temperature of the body, impairs the whiteness of the body and increases the coefficient of linear thermal expansion.

\section{Acknowledgements}

This work was financially supported by the Czech Science Foundation, research project No. P104/13/ 23051S "Anorthite porcelain body on the basis of aluminous cement".

\section{REFERENCES}

${ }^{1}$ W. Tai, K. Kimura, K. Jinnai, A new approach to anorthite porcelain bodies using nonplastic raw materials, Journal of the European Ceramic Society, 22 (2002) 4, 463, doi:10.1016/S0955-2219(01) 00317-X

${ }^{2}$ R. Sokolář, L. Vodová, Whiteware Bodies without kaolin, Interceram., 63 (2014) 1-2, 19-21

${ }^{3}$ X. Cheng, S. Ke, Q. Wang, H. Wang, A. Shui, P. Liu, Fabrication and characterization of anorthite-based ceramic using mineral raw materials, Ceramics International, 38 (2012) 4, 3227-3235, doi:10.1016/j.ceramint.2011.12.028

${ }^{4}$ M. U. Taskiran, N. Demirkol, A. Capoglu, A new porcelainised stoneware material based on anorthite, Journal of the European Ceramic Society, 25 (2005) 4, 293-300, doi:10.1016/j.jeurceramsoc. 2004.03.017

${ }^{5}$ A. De Noni, D. Hotza, V. C. Soler, E. Sanchez Vilchez, Effect of quartz particle size on the mechanical behaviour of porcelain tile subjected to different cooling rates, Journal of the European Ceramic 


\section{R. SOKOLAR: NON-TRADITIONAL WHITEWARE BASED ON CALCIUM ALUMINATE CEMENT}

Society, 29 (2009) 6, 1039-1046, doi:10.1016/j.jeurceramsoc.2008. 07.052

${ }^{6} \mathrm{Y}$. Hirata, Theoretical analyses of thermal shock and thermal expansion coefficients of metals and ceramics, Ceramics International, 41 (2015) 1, 1145-1153, doi:10.1016/j.ceramint.2014.09.042

M. Potuzak, M. Solvang, D. Dingwell. Temperature independent thermal expansivities of calcium aluminosilicates melts between 1150 and $1973 \mathrm{~K}$ in the system anorthite-wollostanite-gehlenite (An-Wo-Geh): a density model, Geochim. Cosmochim., 70 (2006) 3059-3074, doi:10.1016/j.gca.2006.03.013

${ }^{8}$ M. A. Camerucci, G. Urretavizcaya, M. S. Castro, A. L. Cavalieri, Electrical properties and thermal expansion of cordierite and cor- dierite-mullite materials, Journal of the European Ceramic Society, 21 (2001) 16, 2917-2923, doi:10.1016/S0955-2219(01)00219-9 